\title{
Thinking beyond domestic water supply: approaches to advance multiple-use water systems (MUS) in the rural hills of Nepal
}

\author{
Raj K. GC a, Ralph P. Hall a and A. L. (Tom) Hammett ${ }^{b}$
}

a School of Public and International Affairs (SPIA), Virginia Tech, Blacksburg, VA, United States;

b Department of Sustainable Biomaterials, Virginia Tech, Blacksburg, VA, United States

This is the author's accepted manuscript of:

Raj K. GC, Ralph P. Hall \& A. L. (Tom) Hammett (2021) Thinking beyond domestic water supply: approaches to advance multiple-use water systems (MUS) in the rural hills of Nepal, Water International, DOI: 10.1080/02508060.2021.1966976.

\begin{abstract}
The development of multiple-use water systems (MUS) in Nepal has mostly relied on international/non-governmental organizations. Despite the growing interest in MUS within the country, the approach has not yet received space in government policy and programmes, limiting its wider implementation. We seek to understand both the challenges to, and strategies for, scaling-up MUS, especially with regard to how MUS could be incorporated into Nepali institutional and policy processes arising from the adoption of a three-tier (federal, state and local) federal governance system. Our recommendations are informed by a study of MUS in the middle hills of Nepal.
\end{abstract}

\section{KEYWORDS}

Multiple-use water systems (MUS); international/nongovernmental organizations; policy; scaling-up; federal governance; Nepal 


\section{Introduction}

In the 1990s and early 2000s, professionals in both the water, sanitation and hygiene (WASH) sector (e.g., International Water and Sanitation Centre - IRC, and CINARA, Cali, Colombia) (cf. Moriarty et al., 2004) and the irrigation sector (e.g., International Development Enterprises - iDE, the International Water Management Institute - IWMI, and Winrock International) (Bakker et al., 1999; Polak et al., 2004; Renwick, 2001) realized that populations were using the water systems designed for single use for other purposes that contributed to community health and wealth. As a result, these groups started promoting systems that supported multiple uses of water. In 2004, representatives from these groups started collaborating with financial support from the Consultative Group on International Agricultural Research (CGIAR) via a project called 'Models for Implementing Multiple-Use Water Supply Systems for Enhanced Land and Water Productivity, Rural Livelihoods and Gender Equity'. This cross-sectoral project operated in eight countries, including Nepal, and its collaborators coined the term 'multiple-use water services' or 'systems' (MUS) to describe the approach they developed (van Koppen et al., 2006, 2009). International development organizations have now piloted MUS in more than 22 countries in Africa, Asia and Latin America (Clement et al., 2019). Van Koppen et al. (2006) defined MUS as:

a participatory, integrated, and poverty reduction focused approach in poor rural and peri-urban areas, which takes people's multiple water needs as a starting point for providing integrated services, moving beyond the conventional sectoral barriers of the domestic and productive sectors. (p. v)

Others have defined MUS as a strategy for the planning, design and management of water facilities to meet people's requirements for water use for various purposes (Hall et al., 2015; van Koppen et al., 2009a). These definitions emphasize community involvement, institutional development and training, as well as physical design characteristics.

Led by iDE, MUS installation began in Nepal in the early 2000s with fieldtesting followed by the deployment of pilot systems in 2003 (Mikhail \& Yoder, 2008; van Koppen \& Smits, 2012). iDE had previously developed micro-irrigation systems to improve the efficiency of vegetable production, but had found that growers nonetheless also had to carry water from remotely located water sources to irrigate their plots. To address that concern, iDE designed a 'hybrid model' featuring gravity-fed piped water to provide drip irrigation to targeted sites. These became known as multiple-use water systems (MUS). The design prioritized drinking water as per government policy, but also efficiently provided water for increased vegetable production on 'Bari' land (land close to households).

Beginning in 2004, following successful pilot testing, iDE-Nepal, Winrock International and local partners began implementing MUS in seven hill districts of Nepal's 77 districts $^{1}$ as a component of a United States Agency for International Development (USAID)-funded Smallholder Irrigation and Market 
Initiative (SIMI) project. The consortium partners implemented the project in a total of 28 districts. In 2008, Nepal's Ministry of Local Development (MoLD) officially $^{2}$ allowed village development committees (VDCs), the then lowest administrative unit of the government, to invest in MUS development via agriculture block grants. At the same time, however, separate government agencies (the ministries of Water Supply and Sanitation and Irrigation) with differing policy goals were then also independently providing overall drinking water and irrigation system investments; a fact that constituted a substantial barrier to MUS implementation. Indeed, governmental division of authority and lack of inter-agency coordination has greatly reduced Nepal's capacity to scaleup MUS to date. Scholars show that the government's sectoral polices for drinking water and irrigation have remained an impediment for the institutionalization of MUS within government authorities (Basnet \& van Koppen, 2011; Pradhan et al., 2019).

Previous studies have found that household garden plots and livestock production supported by rural water systems can contribute significantly to local economies (GC et al., 2019; Moriarty et al., 2003). Successful MUS implementation in 10 communities in the middle hills of Nepal, for example, increased those villages' median annual income by US $\$ 156$ per household when compared with households using a system designed solely for domestic water use (GC et al., 2019). In general, previous analyses have found that MUS can be effective in generating income and improving people's livelihoods (Hall et al., 2017; Mikhail \& Yoder, 2008; van Koppen et al., 2006). As of 2018, iDE and its partners had facilitated the development of 499 MUS projects in 33 of Nepal's 77 districts. Together, those efforts now touch more than 80,000 people. $^{3}$

As a result, Nepal has emerged as an advanced international example of bydesign MUS system development (van Koppen \& Smits, 2012). In February 2016, like-minded organizations within the country created a MUS network for advocacy, learning and mutual sharing concerning these initiatives. While the efforts of iDE and its partners have raised the profile of MUS in Nepal, its development to date has nonetheless largely been driven by donor funds. Meanwhile, it has received little support or attention in national water policy dialogues and programmes (Clement et al., 2019). This lack of sustained consideration among national officials has made it difficult to establish the socio-political legitimacy of MUS (Clement et al., 2019).

Several authors have discussed approaches to encourage MUS scale-up in peri-urban and rural contexts (Basnet \& van Koppen, 2011; Mikhail \& Yoder, 2008; Pradhan et al., 2019; van Koppen et al., 2006). These analysts have argued that, above all, such water systems should be viewed first as an approach to service delivery, rather than as an engineering scheme (Faal et al., 2009). In addition to this requisite, MUS also requires institutional development and social capacitybuilding if it is to be fully realized. In fact, water professionals who have worked in the traditional hierarchical governance structure in Nepal have argued that increasing the adoption of MUS demands a significant change in how government 
authorities have traditionally delivered water services. Such changes will need to address technical, institutional, financial, political and geographical considerations.

Of these concerns, perhaps the most important is political: a well-functioning and accountable government is an important precondition for sustainable and replicable MUS (Mikhail, 2010; Mikhail \& Yoder, 2008). Moreover, users will need support to manage integrated water services and access markets and necessary technology once MUS have been established (Mikhail \& Yoder, 2008). This support requires a governing policy in which water services, production and marketing activities are collectively addressed. In turn, accomplishing that goal requires coordinated efforts among all relevant public and private actors involved (GC, 2016). However, those stakeholders will need to develop a range of capacities to realize this goal. For instance, they often lack knowledge about appropriate planning and use of water resources, production systems and related benefits.

While, as noted above, income from MUS water use on small vegetable plots (Smits et al., 2011) and from livestock, dairy, bio-gas, horticulture and alcohol production (GC et al., 2019) has the potential to provide financial and social benefits, Pradhan et al. (2019) have contended that Nepali government policies need first formally and broadly to recognize MUS's economic and social development value and create financial and institutional arrangements to support it. A critical aspect of securing that goal will be sharing information concerning the benefits of these systems with potential stakeholders. For example, there is evidence that the revenue from water-based production activities allows farmers to effectively maintain those systems (Moriarty et al., 2004; Pradhan et al., 2019). Nonetheless, such a social, financial and institutional shift cannot occur without reliable delivery of water (van Koppen et al., 2006), equal and effective user access to relevant information and technology (Mikhail \& Yoder, 2008), user participation in MUS system planning and development and adequate financing and coordination of actors across political and economic sectors (Binswanger \& Nguyen, 2005). These factors highlight the breadth of issues that Nepal's national and local governments and development agencies must consider when planning multi-use water system programmes.

Nepal adopted a new constitution in 2015 aimed at reorganizing the government into a three-tier federal system, which formed one national, seven state and 753 local governments. ${ }^{4}$ The local governments were further divided into 6743 wards. Local governments now have the authority to deliver basic public services such as education, health, agricultural extension, rural roads and water and sanitation. The central government provided all basic services through district and village development committees until 2017. The national parliament passed the Local Government Operational Act in that year to define the obligations and functions of the country's new local governments. The adoption of a new federal structure has created an opportunity to integrate MUS into water policy at all governance levels. Nonetheless, that possibility can only 
be realized if such systems are successfully administered at the local level, which requires that the nation's new local governments possess sufficient resources, staff and expertise to do so, and that farmers also develop the necessary knowledge and wherewithal to participate.

While a growing body of research on MUS in Nepal is emerging, past studies have not explicitly sought to describe the various capacities and knowledge required at the different levels of government and among donors, international/non-governmental organizations (I/NGOs) and interested external parties to implement and scale-up MUS. Accordingly, this article examines two broad questions:

- What are the main challenges to the wider adoption of MUS in the middle hills of Nepal and how do a sample of principal stakeholders view those concerns?

- What conditions, institutional arrangements and support mechanisms do stakeholders perceive as important to attain more intensive adoption and successful implementation of MUS?

In partial response to these questions, we developed a model for the implementation and scaling-up of MUS based on the results from both our fieldwork and analyses of previous MUS implementation efforts.

The remainder of the paper is structured as follows. The next section outlines the data collection and analysis methods. The third section presents the findings and discussion, and examines the role of government and non-governmental institutions, including I/NGOs and for-profit service providers in MUS development and operation. The fourth section discusses the factors mediating MUS scale-up and potential ways to address them. The fifth section concludes the paper.

\section{Method for data collection and analysis}

We used a cross-sectional research design to obtain the field data for this research. iDE-Nepal provided the lead author with access to MUS data sheets containing detailed information on MUS projects, including their installation timelines, funding sources, etc. Using existing rural water supply profiles and input from local stakeholders, three wards (Annapurna-6 of Kaski district, Waling-5 of Syangja district and Bagnaskali-1 of Palpa district) were identified as having the largest number of long-term MUS systems in Nepal. The three sites - or 'wards' - are administered under local government units known as 'palikas'. All 60 water systems within the three wards were visited to identify 10 that served more than 10 households each, had no parallel water networks serving them and did not serve users located beyond their delimited boundaries. Each water system was managed by a water committee (known locally as a water users association - WUA).

The study sites of Kaski and Syangja are located in the state of Gandaki, and the remaining site of Palpa is located in Lumbini. Since the palikas obtain 
financial resources and technical support from the state and federal governments, and follow state and federal policies, a series of interviews were held with key informants at each level of government, as outlined below.

\section{Personal interviews}

The lead author interviewed 50 key informants at the community, state and national level between June 2017 and July 2018 (Table 1). The key informants were selected using 'snowball sampling' in which the lead author asked those interviewed to suggest other individuals whom they thought could contribute to the study. This process complemented the researcher's knowledge of local stakeholders which resulted in a comprehensive set of informants. Semistructured interviews were used to understand the experiences and views of these stakeholders concerning MUS and whether and how the approach might be implemented more broadly in Nepal. The lead investigator personally contacted the key informants and undertook the interviews. Each interview averaged approximately one hour in length and was conducted at a location chosen by the participant.

A larger number of individuals from I/NGOs (agriculturalist and social mobilization officers) and water supply engineers/experts were chosen for interviews because of their involvement and experience with MUS planning and implementation. The water supply engineers/experts were either government or NGO staffers or working as a freelance consultant trained in the planning, design and implementation of rural water systems. While a large number of government officials familiar with MUS were contacted for an interview, the majority had either transferred to other state offices or were not available for an interview. The WUA representatives who were selected for an interview were both the former and current officials with the longest service in these associations. Given the role of collection centres/agricultural cooperatives in providing production and marketing services to smallholder famers, representatives from these entities were also interviewed. Several members of political parties at all levels of government were interviewed, given their critical involvement in water-related decision-making. The farmers interviewed were mostly producers who received extensive production training support and grew crops for sale. Of the 50 key informants, $40 \%$ were female and $60 \%$ male. 
Table 1. Number of personal interviews by type of organizations.

\begin{tabular}{|c|c|c|c|c|}
\hline Key informants & Central & State/district & $\begin{array}{c}\text { Local } \\
\text { (palikas/ward) }\end{array}$ & Total \\
\hline Government representatives & 3 & 1 & 3 & 7 \\
\hline $\begin{array}{l}\text { International/non-governmental } \\
\text { organization (I/NGO) staff }\end{array}$ & 5 & 2 & 3 & 10 \\
\hline Water supply engineer/expert & 7 & 3 & 2 & 12 \\
\hline $\begin{array}{l}\text { Water users association (WUA) } \\
\text { representatives }\end{array}$ & - & - & 5 & 5 \\
\hline Farmer representatives & - & - & 5 & 5 \\
\hline Collection centre/cooperative officials & & 2 & 2 & 4 \\
\hline Political party representatives & 1 & 1 & 3 & 5 \\
\hline Private sector representatives & - & 2 & - & 2 \\
\hline Total & 16 & 11 & 23 & 50 \\
\hline
\end{tabular}

\section{Focus groups}

Ten focus group discussions (FGDs) were convened with WUA representatives from the 10 sample systems. WUAs oversee the operation and maintenance of each water system according to locally adopted norms. The lead author approached user group members, along with other water users, to form 7-12member focus groups to obtain their perspectives on the productive use of water and MUS adoption and management. Across the 10 FGDs, 72 representatives participated from 10 WUAs, out of which 29 (40\%) were female. Approximately $40 \%$ of the participants in each FGD were female. Similarly, $50 \%$ of the representatives were upper caste (the highest hierarchy of social group in a Nepali cultural system), 20\% Dalits (the lowest hierarchy of social group) and 30\% Janajatis (an ethnic group with a distinct cultural identity). Using the local language, the lead author explained the study objectives and facilitated an interactive discussion covering a range of MUS-related topics. The participants were also asked to discuss the barriers that might limit the replication of MUS and for their views concerning how those issues might be overcome. The participants were given sufficient time to discuss each topic and come to a group consensus on specific issues. Any divergent perspectives were also documented. The FGDs took place in a location in the community chosen by the participants.

\section{Data coding and analysis}

The responses obtained from the personal interviews and focus groups were 'hand coded' (Creswell, 2012) and the key variables and themes that emerged were triangulated with the results from other relevant sources of information (Vogt et al., 2014). We coded the interview and focus group responses using a five-stage process suggested by Creswell (2012). Each transcription was carefully reviewed, and the text was divided into topical themes. These themes were then consolidated as needed to reduce overlap and redundancy. The resulting themes captured the major findings from this research. Unless otherwise specified, when we reference our empirical work, the analysis that follows explores the findings through the key 
informants, who are identified by their role.

\section{Results and discussion}

\section{Scale-up challenges: evidence and stakeholder perspectives}

Securing adequate and consistent funding for MUS has been a central challenge to scaling-up such efforts historically in Nepal, and that concern remains today. Figure 1 shows the number of MUS systems installed by iDE-Nepal and its partners between 2004 and 2018, and their corresponding costs. It reveals how MUS development has risen or fallen each year with the availability of funding, primarily from external sources. While the government of Nepal has provided significant financial support (21\% of funding), MUS is currently disproportionately dependent on iDE and its international funders (30\%). Other sources of funding include community-based organizations and partner I/ NGOs $(8 \%)$, community/users funds $(12 \%)$ and in-kind contributions from residential water users, such as unskilled labour and local materials including, sand, gravel and stone (29\%). This breakdown suggests that international donors remain the largest contributors to MUS development and implementation.

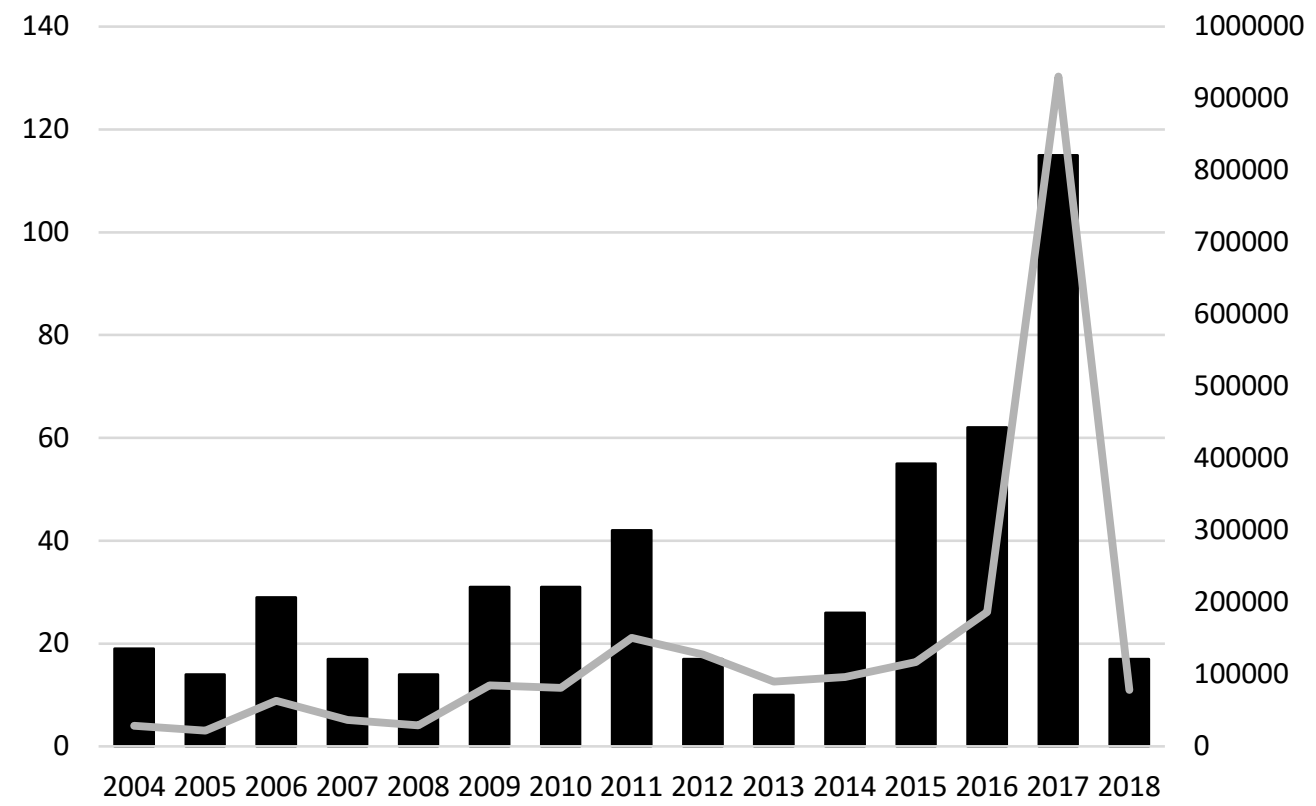

No. of MUS Total Project Cost (USD)

Figure 1. Multiple-use water systems (MUS) project implementation and cost in Nepal, 2004-18. Source: International Development Enterprises (iDE) MUS data sheet.

Since 2004, iDE and its partners have implemented more than 11 livelihood related projects that included MUS as a central component. These initiatives depended in part on ad-hoc government funding whose allocation arose from 
officials' awareness of this water system alternative and their previous ties to implementers.

iDE's support for local NGOs has been a critical catalyst for MUS development in Nepal. Once a jurisdiction commits to such an initiative and its planning is underway, iDE consults with government officials and other potential partners to obtain matching support. This lengthy and uncertain approach to project development, in which public funding is secondary to donor support, is not a sustainable model according to a majority of those interviewed. Three-quarters of our key informants argued that the limited scale-up of MUS in Nepal to date has arisen in significant part from the continued institutional siloing of government water-related responsibilities. For example, the Department of Irrigation (DoI) oversees only its namesake projects, the Department of Agriculture (DoA) only agriculture programmes, and the Department of Water Supply and Sewerage Management (DWSSM) only water-supply-related initiatives. Such sectoral disparities between the WASH and irrigation sectors have been a key barrier to the wider replication of MUS in Nepal (Basnet \& van Koppen, 2011; Clement et al., 2019; Pradhan et al., 2019). These institutions presently do not routinely coordinate their efforts, which is essential to successful MUS implementation. Moreover, none of these authorities has formally recognized the productive capacity of rural water systems. That is, officials at all levels of government continue to embrace a single-use view of water service provision. This finding is consistent with Rautanen et al. (2014) who argue that both project implementors and communities in mid-western Nepal typically have a conventional single-use mindset. Consequently, our key informants contended that government decisionmaking is rarely based on evidence-based assessments of service needs. This finding reflects a limited national understanding of MUS (Clement et al., 2019). In addition, public agencies seeking to develop or improve existing water systems typically do not examine alternatives to traditional water service delivery approaches (interview with a water supply expert, Kathmandu). The general lack of socio-political support for institutionalizing MUS in Nepal creates a barrier for policy change in this area (Clement et al., 2019).

More broadly, our interviews suggest that key government decision-makers were generally not well informed about MUS or its livelihood impacts. This was so despite the fact that WASH remains a major government development priority. Indeed, our key informants did not provide any evidence that the WASH sector has contributed to MUS development. Instead, those we interviewed who were active in that domain tended to view the productive use of water as a constraint on its supply for domestic uses. The MUS proponents we interviewed did not accept this absolute opportunity cost argument, but nonetheless contended that the domestic needs of a community must first be met before other productive uses are considered.

While the major share of participants in our focus groups reported MUS as a potentially important asset for rural communities, half of those engaged expressed concerns related to the risks of water-based production. They specifically cited possible crop failure, pest infestations, poor access to markets, 
low market prices, natural disasters and a lack of access to agricultural inputs, production technologies and financial services as concerns (GC \& Hall, 2020). These factors had discouraged many small-scale farmers from adopting MUS.

MUS can serve as an integrator across many sectors, especially the water and agriculture sectors (Hall et al., 2017). The lack of coordination among the government's sectoral departments/staff (i.e., water and agriculture) at the local, state and national levels can be a key challenge to realizing the effective implementation of MUS (FGDs). Since MUS are more complex than single-use systems (Clement et al., 2019) and present a new water service delivery approach to the government and many other organizations, there is a MUS capacity gap that needs to be addressed.

\section{Strategies for scaling-up MUS}

By combining the views of the key informants with the findings from the focus groups and household surveys (GC et al., 2019, 2021), we identify a range of strategies that, if widely adopted, could encourage the wider acceptance and use of MUS in the hills of Nepal. We have organized our discussion of these concerns into six categories of mediating factors, which we discuss in turn in the sections that follow: nascent local governments as the principal agents of governance responsible for MUS; government official, user and private supplier capacity-building; palika multi-use water systems registration; improved coordination and collaboration among different sectoral actors and across levels of governance involved in water provision and management; more effective policy advocacy by MUS proponents and changes in national policy that formally recognize these systems and coordinate to support them among relevant departments; and sustained international donor support for MUS. We have summarized these concerns in Figure 2, which illustrates a potential arrangement for scaling-up MUS in the rural middle hills of Nepal. In this scenario, local governments would oversee the design and execution of approved projects based on own-source funding as well as federal (national government) and donor transfers. WUAs would implement local governmentapproved projects with the technical and facilitation support of local NGOs.

For this approach to work, all funders, including national and state governments as well as external agencies, would need to coordinate their policies and activities closely to support local governments. Palikas and WUA representatives would meanwhile also have to collaborate to ensure effective project implementation. We discuss potential arrangements for MUS scale-up in greater detail in the following sections.

\section{Local government as the principal governance agent responsible for MUS}

As we have highlighted, the 2015 Nepal federal constitution charges all three tiers of government with some share of responsibility for water management (Government of Nepal, 2015; Kyle \& Resnick, 2016). Schedule-8 (list of locallevel powers) of the constitution and Clause 3 of the Local Government 
Operational Act of 2017 (functions, duties and powers of local governments) grant local governments legislative and executive purview over service delivery for water supply, small hydropower projects, agriculture and animal husbandry, agro-products management, animal health, grower cooperatives, local support services and market management, environmental protection and biodiversity, among other responsibilities. The federal and state governments are charged with overseeing large-scale water projects.

The Local Government Operational Act (2017) provided local governments authority to enact laws to guide water service needs in their jurisdictions, as long as those do not conflict with federal and state statutes (Government of Nepal, 2018). This is to say that local governments possess the necessary formal authority to create laws, plans and budgets to promote MUS on an ad-hoc basis. The constitution and the Local Government Operational Act (2017) called on those entities to plan, budget and implement development programmes within their capacity and resources (Government of Nepal, 2018). Final budget authority for such initiatives rests with the relevant palika assembly. ${ }^{5}$

Most of the key informants (85\%) we interviewed argued that local government officials should take a lead role in MUS planning and implementation because they know local realities, needs and resources the best. More particularly, these individuals also suggested that local governments should manage some MUS funding. According to a significant share of our focus group participants and key informants, this was so, in part, because they feared that if palikas were not designated as chief project implementers, their leaders might well lose interest in, and refuse to accept ownership of, MUS design and realization. Put differently, local governments should lead the rural development agenda to ensure that that level of governance would become more responsible for addressing citizen's needs. Pradhan et al. (2019) and Clement et al. (2019) also contend that local governments should be responsible for MUS development and granted sufficient decision-making authority and financial autonomy to address those aims. In light of these findings, MUS represents a new challenge for most Nepali localities and actors. As a result, existing staff might not be able to effectively oversee the implementation of such water projects because they lack resources, understanding and technical capabilities. 


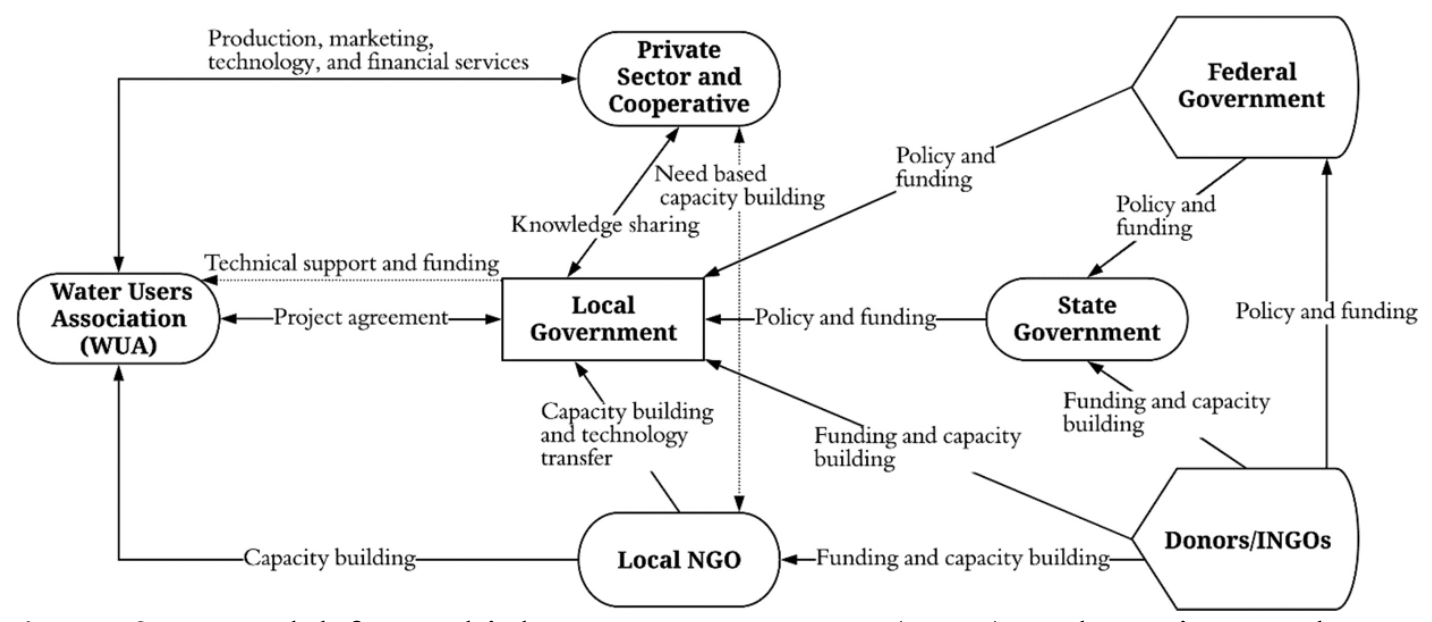

Figure 2. A model for multiple-use water systems (MUS) scale-up in Nepal. Source: Authors.

The role of local governments in MUS scale-up. More generally, the vast majority of our key informants contended that MUS should be fully institutionalized as a standard programme within Nepal's local governments. These individuals argued that local government responsibilities should include: (1) an annual planning and budgeting process for MUS projects; (2) securing necessary resources for system development and realization; and (3) ensuring that farmers receive multiple forms of support to adopt and implement MUS. We discuss each of these areas of potential local government MUS responsibility in greater detail below.

Annual planning and budgeting for MUS projects. Prior to January 2018, when the new federal system went into effect, NGOs and village development committees implemented MUS projects on an ad-hoc basis. Now, however, local governments are at least formally well positioned to manage the planning and budgeting for such systems. To do so effectively, however, those governments must provide villagers an opportunity to identify and rank their priorities for development through a needs-based project identification process mandated by the constitution. Once a majority of residents have opted for a suite of potential initiatives, those must next be approved by the village ${ }^{6}$ and palika assemblies.

Securing the necessary resources for MUS development and realization. The Nepali government's fiscal year begins with Shrawan (roughly mid-July) and local governments must prepare their annual budgets a year ahead of that date to secure sufficient time for review. However, the I/NGO planning cycle largely depends on donor approval of funding and subsequent subcontracts with local NGOs. The mismatch of I/NGOs planning schedules with those of the government has created a challenge when efforts require combining resources from these sources. This suggests that I/NGOs could shift their planning timelines so they align with those of local governments to allow for pooling of funds for MUS 
by local governments. Donors will also need to approve any such changes.

Farmers must receive multiple forms of support to adopt and implement MUS. A large share of our key informants argued that farmers must receive training, access to inputs (seed, fertilizer and technology) and marketing and lending services from cooperatives, private entities or agency service providers for MUS to be implemented effectively. GC et al. (2019) conducted a study of 202 households in the middle western hills of Nepal as part of this same study and found that MUS must include a range of technologies and services for farmers to help them scale-up production activities. These include crop production technologies (e.g., irrigation systems, integrated pest management, appropriate seeds and low-cost greenhouses) and a number of additional services (agricultural input-suppliers, micro-credit, crop collection centres and marketing). GC et al. (2019) found that the odds/possibility of a household being in the high production income group (compared with the low group) increased 407 times when a household used a combination of productive technologies compared with those who do not use these technologies. Most households who used these technologies also used the production services, as reported above. These results suggest that these services, when used in an integrated way, have a positive impact on production and related incomes.

\section{Government, user and private sector capacity-building}

Capacity-building of $\boldsymbol{W U} \boldsymbol{A}$. Most stakeholders understand and support the role NGOs play in helping user project committees (such as WUAs) develop agreements with them to manage the MUS development process, including engagement with support service providers such as micro-lenders, private suppliers and cooperatives. Those managing any MUS project operating within a palika will need to interact extensively with local and state officials and the district coordination committee (DCC). ${ }^{7}$

Typically, a WUA oversees the development, management and operation of a water system, guided by a locally adopted agreement. Establishing an effective institutional structure consistent with local customs and norms requires considerable facilitation skills and targeted capacity-building. In addition to the operation and management of MUS, WUAs partner with local agro-vets and extension agents to provide training and technical assistance to farmers. Our FGDs with WUA members revealed that at least two system operators per water system need to receive 2-3 months of professional training to repair and maintain MUS systems. Because many young men work abroad, primarily in the Middle East, women assume much of the responsibility for smallholder crop production (GC et al., 2019). This informs a need to train women to serve as operators. A local NGO official experienced in MUS implementation explained:

We provided MUS installation, operation, and maintenance trainings to at least one man in each MUS community. We also provided a training completion certificate to them. It was disappointing that many of them went abroad for jobs. We also learned that the 
certificate we provided helped them to secure those jobs. We have realized that it is important to train at least one woman and one man as an operator per system.

Capacity-building oflocal, state and federal governments. Individual palikas are now tasked with evaluating local water needs and establishing funding priorities to address them. Thus, it will be critical to engage and train palika officials in developing such evaluations to ensure that productive uses of water, such as vegetable cultivation, are considered during their deliberations. Further, nearly half of our key informants (48\%) confirmed the need to educate local officials on the engineering, agriculture and social mobilization requirements of MUS developments. Understanding the support services and technologies necessary for such projects will allow palikas to position the systems they operate for success. This suggests that MUS planning and implementation training should be provided to local government engineers. I/NGOs that have implemented previous MUS projects are well equipped to provide such assistance.

Three-quarters of our key informants reported that workshops, publications and learning alliances involving government, NGOs and other relevant stakeholders at the federal, state and local levels constitute an important mechanism for sharing knowledge related to MUS. One MUS expert informant argued, for example, that, in his experience, the more officials understood the idea and the greater their familiarity with it, the more receptive they were to it.

Capacity-building for farmers to create MUS. A majority of our key informants $(70 \%)$ reported that there is substantial demand for this approach in communities whose growers had received an orientation to its characteristics and aims and who had undertaken a site visit to a successful project. Such visits have proven to be a compelling way to educate people about MUS and thereby to expand interest in the approach.

Relevant training and visits to successful farms had equipped growers to become more effective commercial producers (interview with an NGO Staffer, Syangja). This assistance occurred within farmer groups in communities and at collection centres or local agricultural cooperatives. In three successful MUS communities where collection centres or agricultural cooperatives were wellestablished and private sector input suppliers and micro-finance institutions were accessible, nearly three-quarters of the household respondents suggested they were benefiting from production training and access to those services. This implies that WUAs need to ensure that farmers have access to specific capacitybuilding opportunities to develop the capabilities for which they will need thereafter to be responsible. An agricultural input supplier (i.e., agro-vet) may demonstrate drip irrigation or hybrid seed varieties, while a collection centre/cooperative representative might recommend a particular timing and quantity of crop varieties. Farmers seeking a production loan from cooperatives or micro-credit lenders learn how to maintain records and track payment. In short, a wide range of service providers need to become engaged in the training of producers to equip them with the knowledge and skills necessary to become successful commercial farmers. 
Capacity-building of federations, cooperative and private sector actors. More than two-thirds of our key informants (70\%) suggested that I/NGOs could educate the Federation of palikas, leaders of cooperatives and agro-vet staff members on the requirements for MUS. Agro-vets can also inform and orient NGOs and production groups on the availability of improved inputs and production techniques. The Federation of Palikas, an association of elected representatives serving in those bodies, can directly influence other actors as they consider MUS adoption. Cooperatives typically represent several farmer groups' interests and also provide credits for agricultural production. Agro-vets provide agricultural inputs and related services to MUS farmers.

\section{Coordination and collaboration among different sectors and governmental levels.} More than half of our key informants (52\%) identified horizontal coordination among agencies and vertical coordination among local, state and federal agencies as being critical to effective and efficient MUS service delivery. A factor complicating this coordination is that government agency officials typically have a top-down mentality. Indeed, one of the primary barriers to successful implementation of the new constitution is a 'centralized mindset', not only at the centre of government but also at the state level (interview with a political leader, Syangja). Thus, it is important to overcome such a bias and respect local priorities and claims. For example, the state infrastructure, agricultural, social welfare and environmental ministries will need to listen and support local government MUS priorities, rather than offer directions.

As we noted above, all three levels of government - federal, state and local enjoy some measure of authority for water supply. This overlap has not yet been fully clarified by federal legislation and uncertainty about roles and responsibilities will likely continue until such can occur (World Bank, 2018). In fact, this situation gives the nation and states some control over local government policymaking. It is therefore important that the federal and state governments respect and support local government MUS-related policy decisions that meet the law and their accountability requirements. Under the new governmental system, the DCC will play a critical role in shaping policy as they are expected to mediate disagreements between local government officials and federal and state ministries. Hopefully, the DCCs will be able to resolve policy roadblocks and conflicts to MUS development by working closely with representatives of higher level governments.

I/NGOs and government also must collaborate to share knowledge and good practices. The majority of our water supply expert key informants $(80 \%)$ suggested that MUS implementers should incorporate their efforts into a basinwide examination of water sources through the preparation of water use master plans (WUMP) that set the development priorities for each water source. MUS can become a central part of the WUMP when such planning occurs (Pradhan et al., 2019; Rautanen et al., 2014). Indeed, I/NGOs can provide training to local government engineers and officials to integrate MUS into WUMP efforts. Such 
a strategy would require considerable collaboration among MUS and WUMP related organizations and approval from local and state ministry officials.

\section{MUS registration by palikas}

The 1992 Water Resources Act (2049 BS) and the 1993 Water Resources Rules (2050 BS) authorized district water resource committees ${ }^{8}$ (DWRCs) to register WUAs (Government of Nepal, 1992). However, these government actions did not recognize MUS WUAs, because MUS is not yet formally recognized as a distinct approach to water delivery at any level of Nepali governance. As a result, unlike drinking water and irrigation WUAs, MUS WUAs have never found a space in national federations. This situation prohibited them from advocating for MUS in national policy platforms. One of the experienced water supply experts argued that MUS promoters focused more on achieving MUS targets set by donors than on enhancing the capacity of MUS WUAs for selforganization. In addition, the expert argued there was no evidence that the MUS promotors effectively engaged DWRC in MUS planning processes.

Since DWRCs do not exist in the current governance structure, palikas now manage MUS registration (water source and WUAs), but they do so inconsistently. That is, while some palikas have formally registered MUS, others have declined to do so. Those that have refused have argued that these systems are not formally recognized in national government policies. iDE MUS guidelines highlight the importance of securing such registration, but there are only a few examples when this has occurred. As one chairperson of an MUS WUA commented in an interview:

We went to the district water resource committee to register our water source. Unfortunately, the committee refused to register the source with a name 'multiple uses' added to it. They mentioned that the existing registration guidelines did not allow them to register the source. It was important for us to register the source to formally secure its ownership. Therefore, we registered the source without mentioning 'multiple use'.

More than two-thirds of our key informants (70\%) stressed the need to establish a clear and streamlined MUS registration process at the local level. Arguably, if MUS is formally recognized in policy, registration will be required at the same time. Similarly, Pradhan et al. (2019) have argued that palikas should formally assume responsibility for water system registration and/or renewal of water sources and user groups. However, it is not yet clear whether local governments will be willing to assume such a role without MUS first being recognized in national policy. This again suggests the important question of why MUS policy is not changing at the national level. We respond this specific concern in the section below.

\section{More effective advocacy and changes in policy}

A large share of our key informants argued that the lack of a clear and supportive national government policy impedes MUS development. Taking MUS 
approaches to scale will require that responsible ministries change their strict approach to single-use domestic water supply (Clement et al., 2019), which serves the needs of the WASH sector, but fails to accommodate productive uses. This situation remains one of the biggest challenges in planning and funding MUS. A local political leader contended that governments limited understanding of economic benefits from small-scale productive uses combined with a lack of stakeholder collective action to press the government to make that change has led to this situation.

Scaling-up MUS in Nepal also requires further documentation of the challenges and benefits of ongoing efforts (Basnet \& van Koppen, 2011). Indeed, a significant MUS information dissemination campaign would need to make government officials and political leaders aware of the advantages of this approach and, thereby, hopefully, to gain their support for a change in policy to support such systems. These materials should be packaged to appeal to a variety of target audiences. For example, state officials within the Physical Infrastructure and Development Ministry might be particularly interested in the design aspects of MUS, while the Land Management, Agriculture and Cooperative Ministry would be more interested in the support services needed by farmers (e.g., production and marketing supports linked to MUS). Potential users could also use such information to make informed choices concerning their participation in MUS efforts.

A highly experienced water resource development professional involved in the devolution of irrigation management to local user associations argued in his interview that a MUS network or similar group could assume responsibility for sharing information with potential stakeholders. This network could also advocate for needed local government policies by working closely with the Federation of Palikas (interview with an INGO representative, Kathmandu). This group could also work with the National Federation of Irrigation Water Users' Association (NFIWUAN) and the Federation of Drinking Water and Sanitation Users Nepal (FEDWASUN) at the national level to advocate for needed policy changes and implementation practices, as shown in Table 2. 
Table 2. Proposed institutional/policy changes for scaling-up multiple-use water systems (MUS).

\begin{tabular}{|c|c|}
\hline Current & Proposed \\
\hline Primary funding from donors & $\begin{array}{l}\text { Primary funding from Nepali } \\
\text { governments }\end{array}$ \\
\hline Short-term project approach & Long-term programme approach \\
\hline $\begin{array}{l}\text { International/non-governmental } \\
\text { organizations (I/NGOs) } \\
\text { implementers }\end{array}$ & $\begin{array}{l}\text { Local government as the major } \\
\text { implementer and NGOs in a capacity } \\
\text { development and supportive role }\end{array}$ \\
\hline Sectoral coordination & $\begin{array}{l}\text { Inter-sectoral coordination among actors } \\
\text { in the water, sanitation and hygiene } \\
\text { (WASH), agriculture, irrigation, rural } \\
\text { infrastructure and environmental sectors }\end{array}$ \\
\hline $\begin{array}{l}\text { Water users' association (WUA) as the } \\
\text { operational and managerial entity }\end{array}$ & $\begin{array}{l}\text { Multifunctional user group (with the } \\
\text { additional role of facilitating access to } \\
\text { technology, support services and } \\
\text { markets) }\end{array}$ \\
\hline MUS planning initiated by NGOs & $\begin{array}{l}\text { Local governments assume responsibility } \\
\text { for planning and budgeting for MUS }\end{array}$ \\
\hline
\end{tabular}

\section{MUS funding by international donors}

As noted previously, international donors remain the largest contributors to MUS development in Nepal. In practice, it is unlikely that localities will soon obtain adequate funding from the federal government as per their formal mandate due to its limited financial resources. In addition, the constitution and the Intergovernmental Financial Arrangements Act 2017 provide little guidance concerning which funding mechanisms should be used to support specific functions (Boex, 2019). Boex (2019) further argues that such a limitation can make local government officials less accountable for their public service responsibilities. For instance, they can make funding decisions based on their own interests due to a lack of clarity on what public infrastructure or functions need to be supported. As pointed out above, local governments have limited financial resources to implement these services including MUS. Given these constraints, a majority of our key informants and focus group participants argued that international donor contributions are now and will remain critical in the foreseeable future to ensuring adequate local government budgets for MUS planning and development in Nepal.

Schedule-5 (list of federal powers) and Schedule-6 (list of state powers) of the constitution grants federal and state ${ }^{9}$ governments legislative and executive authority over foreign grants. National government policy currently bars local governments from signing aid agreements with international donors. However, local governments are charged with implementing donor-funded public service projects (e.g., rural infrastructure, agriculture extension, rural water supply, etc.). More than half of our key informants (55\%) advised that local governments should obtain donor funds for hardware (i.e., water system construction) and seek the assistance of I/NGOs for software (i.e., capacity- 
building) to ensure the effective implementation of MUS projects.

\section{Factors mediating MUS scale-up and potential ways to address them}

This section provides an overview of strategies that together could chart a way forward for scaling-up MUS in Nepal. Overall, we found that government and I/NGO officials, and interested external parties and stakeholders active in pressing for MUS, should consider a range of technical, socio-cultural and economic factors when advocating for its widespread implementation. The various stakeholders involved possess differing resources, capacities and knowledge of MUS. Furthermore, all the actors now engaged face the very real challenge of developing these proposed systems amidst capacity constraints and while governmental responsibility allocations are being established.

We expect that local government capacity-building and the related challenge of diffusing MUS knowledge to potential users will prove a long-term process. Making the proposed model we sketched above (Figure 2) function effectively will require time and considerable training and team-building. The government at several levels will have to foster such efforts. It is important to recognize that the success of these strategies will ultimately depend on the ability of localities to pursue them effectively, responsibly and with accountability. It is equally important that federal and state governments and I/ NGOs extend financial and technical support to local governments for the purpose.

\section{Technical factors: capacity-building of local stakeholders in the planning, design, repair and maintenance of MUS}

As we have noted, most local government leaders are most familiar with singleuse domestic water systems concerning water services provision. Indeed, most local governments have had no or limited direct involvement in the planning, design and management of MUS projects. Such officials, including engineers, need to develop a clear understanding of multi-use water system planning and design if this situation is to change. In turn, the NGOs now implementing MUS must work to help build local government capabilities to assume responsibility for their current efforts and do so on an ongoing basis to encourage the possibility of change.

Shifting MUS development responsibility from I/NGOs to local governments will likely require a transition period of several years, during which the knowledge gained from developing and refining the MUS development during the past two decades can be shared with local officials. In this process, I/NGOs can play a critical role in supporting the government (at all scales) with MUSrelated resources and expertise. External resources will be essential to support this capacity-building effort.

\section{Techno-economic factors: access to market and production services}

Local government officials already possess knowledge and capacity concerning 
agricultural production activities. However, this knowledge has yet to be connected with MUS. Given the single-use water services provision mentality among many local government leaders, it will take significant time for engineers and agricultural experts to understand and act on the need for the water and agricultural sectors to work together to advance MUS projects.

The provision of crop and livestock insurance, financial services and credit from the private sector is likely to reduce the fear associated with MUS-based production such as production failures, low crop yields and uncertainty of sales after production. These factors can, and often do, discourage users from undertaking water-based production activities (GC et al., 2019). A core aim of MUS is to encourage commercial-scale production through continued innovation and improvements in water supply systems. Meanwhile, farmers must be able to diversify their crops, spread farm production over the years, and take risks relating to stresses such as weather and market shocks. To achieve these goals, technology suppliers and service providers (technology suppliers, agro-vets, veterinary services, credit services providers, etc.) should establish/expand productive technologies and services supporting MUS. These suppliers make profits from their businesses. As a result, they continue to provide their services to MUS farmers. In this sense, private sector involvement is likely to be critical to expanding MUS.

In summary, the activities of private sector actors need to be harmonized with agriculture cooperatives that provide extension services. In the meantime, local governments must recognize these services as an integral component of their MUS programme.

\section{Socio-political factors: community and government awareness and access to knowledge and information on MUS}

For the concept of MUS to be widely understood by communities, local governments will need to conduct technology demonstrations, information campaigns and workshops at the grassroots level. Such activities should occur as localities develop the capacity to lead/ support MUS outreach, which will likely be a long-term process.

Importantly, local governments have human resource constraints to deliver basic services. In partial response to this gap, I/NGOs may consider sharing their human resources with local governments as part of capacity-building efforts. For instance, I/ NGOs can play their familiar role of working with communities to assess water needs, share resources, create opportunities for crop production and provide technical support. In addition, they can play a critical role in advocating for policies and procedures to accommodate MUS among local governments.

At the state and local level, collaboration among MUS-related groups could take the form of an 'MUS group' within the palikas' federation. Such a group could integrate knowledge and best practices related to WASH, the productive uses of water, and support services and advocate for MUS among state and local government officials. At the national level, the 'MUS network' could establish 
coalitions with kindred organizations with the objective of educating government officials (through workshops, trainings, information campaigns, etc.) on the role of MUS in alleviating poverty in the rural hills of Nepal. It is essential that state and national leaders support local elected officials if MUS is to be more widely adopted.

\section{Economic factors: financial resources and mechanisms for MUS funding}

We have argued that donor contributions will continue to be necessary for scaling-up MUS. In our view, government funding for these systems should increase substantially compared with previous levels, while a larger portion of donor and I/NGO MUS resources should be devoted to relevant stakeholder capacity-building.

Currently, all MUS projects are donor driven and implemented over a 3-5year period. Until adequate national and state MUS policies are established and the basic institutional capacity of local governments to advance such water systems is developed, I/ NGOs will need to continue implementing MUS in an ad-hoc way with financial support from donors. It is important that both I/NGOs and donors recognize their long-term role in advancing MUS by transitioning this role to local governments as soon as appropriate. Local governments may be able to facilitate the work of I/NGOs by creating mechanisms to pool financial resources from multiple sources. Thus, a strong official commitment to the decentralization mandated by the nation's new constitution, along with government and donor willingness to work towards a unified disbursement mechanism for support funds, will be essential for effective MUS scale-up.

\section{Institutional factors: appropriate policies and institutions for the effective planning, implementation and promotion of MUS}

It is necessary that federal and state governments uniformly recognize MUS as a standard approach to rural water service development. However, such policies are unlikely to materialize until government officials at all levels fully understand and accept MUS. In addition, MUS WUAs traditionally function as the operation and management entity for such systems. We suggest that the government develop a policy that allows such groups to work as a multifunctional entity. These entities could then facilitate the linkage of MUS users with agricultural technology, support services and markets. Notably, local government officials are new and will require skills to effectively engage in these policy arenas. I/ NGOs and donors could lobby the national government to enact these policy changes.

\section{Cultural factors: addressing traditional practices, rooted cultural understanding and lack of interest in adopting innovative practices}

A number of our key informants informed us that federal and state government officials may obstruct delegating responsibility for MUS to local governments due to their many years of working in a thoroughly centralized governance framework. Most local government officials simply follow federal instructions. 
Our key informants also contended that many government officials are risk averse, preferring to take conventional approaches to project development, rather than pursuing innovations that might fail. Most government officials are historically trained to implement sectoral projects (i.e., domestic water systems). For instance, they consider MUS challenging because it spans multiple sectors (engineering, agricultural and social mobilization dimensions). This finding, also discussed in previous sections, highlights the importance of educating government officials on the multidimensional aspects of MUS development.

Importantly, the policy (discussed above) will not change until a much larger number of Nepali government officials embrace the idea that people need, and can use, water for multiple uses. Thereafter, change is likely only to come with time and experience as MUS systems demonstrate their potential to change growers' lives.

\section{Conclusions}

This article has examined MUS development in the middle hills of Nepal during the past two decades. Under the new Nepali Constitution, local governments can now play larger roles to advance MUS. However, as we have argued, until formally supportive national and state policies are established and local governments have developed the basic institutional and cultural capacity to advance them, the landscape for MUS is unlikely to be a dynamic one. Further, for communities to be receptive to MUS, local officials should strive to create an enabling environment for collaboration and partnerships among the infrastructure (water supply), agriculture, economic development and social welfare sectors at the local and state levels. We have argued that making the new decentralized governance structure function effectively will itself require time and considerable capacity development efforts at all levels of government, quite part from the required changes necessary to implement MUS more broadly in the nation. We have described the challenges and opportunities that confront leaders and advocates wishing to scale-up MUS implementation in Nepal. Finally, we have outlined a series of recommendations designed to advance such efforts at all levels of government.

\section{Notes}

1. Districts are a tertiary level of government in Nepal and are themselves subdivided into palikas (municipalities). Nepal's seven states contain 77 districts.

2. Nepal's Ministry of Local Development (MoLD) had provided block grants to village development committees before the nation's new constitution was implemented in 2017. The ministry identified a 'small irrigation project' under its agricultural development grant guidelines as a priority area for investment. MoLD today formally considers MUS small irrigation projects. 
3. Source: iDE MUS data sheet.

4. Local governments include municipalities (palikas), constituent wards and DCCs. A palika can contain anywhere from nine to 20 wards, all of which participate in a common planning and budgeting process.

5. Villages are small geographical units of a ward, and several wards together constitute a palika. The palika assembly is a decision-making body that includes the mayor/chairperson and the deputy mayor/vice-chairperson of the municipal executive, ward chairpersons, and four members elected from each ward, as well as members of the municipal executive elected from the Dalit and minority communities.

6. Legislative powers at the local level are vested in the village and palika assembly. A village assembly consists of the chairperson and vicechairperson of the village executive, ward chairpersons, four members elected from each ward, and members of the village executive elected from the Dalit and minority communities (Government of Nepal, 2015).

7. The DCC is a nine-member elected body in each district assembly. Each district has several palikas and its elected officials (by the people) elect nine members to represent the palika in the DCC. The committee coordinates and monitors the development activities of palikas within the districts. It also plays a critical role in resolving conflicts between different palikas, and between palikas and state governments.

8. Prior to 2015, the district water resource committees operated under the auspices of DDCs. These entities no longer exist in the current governance structure.

9. According to the new constitution, the state government can exercise authority over foreign assistance with the approval of the federal government.

\section{Acknowledgments}

The authors would like to thank International Development Enterprises (iDENepal) for providing office space, vehicles and support at various stages of this research. We also acknowledge the support of Khadka Sunar, Bal Krishna Thapa, Him Bahadur DC and Gambar Singh Thapa, who provided logistical support for the fieldwork described in this article. We are also thankful to John Covert for his insightful comments concerning an earlier version of this article. We would especially like to thank Max O. Stephenson, Jr, who reviewed the final draft and provided comprehensive feedback.

\section{Disclosure statement}

No potential conflict of interest was reported by the authors. 


\section{References}

Bakker, M., Barker, R., Meinzen-Dick, R., \& Konradsen, F. (1999). Multiple uses of water in irrigated areas: A case study from Sri Lanka. International Water Management Institute (IWMI).

Basnet, G., \& van Koppen, B. (2011). Multiple use water services in Nepal scoping study. International Water Management Institute (IWMI) and International Rural Water Supply and Sanitation Centre (IRC).

Binswanger, H., \& Nguyen, T.-V. (2005, January 26-28). A step by step guide to scale up community driven development. African water laws: Plural legislative frameworks for rural water management in Africa. Johannesburg, South Africa.

Boex, J. (2019). A critical year for fiscal federalism in Nepal. Decentralization and localization. Retrieved March 10, 2020, from http://www.decentralization.net/2019/01/a-critical-year-for-fiscalfederalism-in-nepal/

Clement, F., Pradhan, P., \& van Koppen, B. (2019). Understanding the noninstitutionalisation of a socio-technical innovation: The case of multipleuse water services (MUS) in Nepal. Water International, 44(4), 408426. https://doi.org/10.1080/02508060.2019.1600336

Creswell, J. W. (2012). Education planning, conducting, and evaluating quantitative and qualitative research (4th ed.). Pearson Education, Inc.

Faal, J., Nicol, A., \& Tucker, J. (2009). Multiple-use water services (MUS): Cost-effective water investments to reduce poverty and address all the MDGs. RiPPLE Briefing Paper. Addis Ababa, Ethiopia.

GC, R. K. (2016, March 24-25). Multiple use water systems and micro irrigation technologies for Koshi basin - lessons from Gandaki region, Nepal. The water-livelihoods-gender nexus to advance Koshi basin management. International Centre for Integrated Mountain Development (ICIMOD).

GC, R. K., \& Hall, R. P. (2020). The commercialization of smallholder farming - A case study from the rural western middle hills of Nepal. Agriculture, 10(5), 143. https://doi.org/10.3390/ agriculture10050143

GC, R. K., Ranganathan, S., \& Hall, R. P. (2019). Does rural water system design matter? A study of productive use of water in rural Nepal. Water, 11(10), 1978. https://doi.org/10.3390/ w11101978

GC, R. K., Ranganathan, S., Hammett, A., \& Hall, R. P. (2021). What factors determine the technical performance of community-managed rural water systems in the middle hills of Nepal? Journal of Water, Sanitation and 
Hygiene for Development, 11(2), 222-230. https://doi. org/10.2166/washdev.2020.189

Government of Nepal. (1992). Water resources act. Government of Nepal. (2015). The constitution of Nepal. Government of Nepal. (2018). Local government operations act.

Hall, R. P., Ranganathan, S., \& GC, R. (2017). A general micro-level modeling approach to analyzing interconnected SDGs: Achieving SDG 6 and more through multiple-use water services (MUS). Sustainability, 9(2), 314. https://doi.org/10.3390/su9020314

Hall, R. P., Vance, E. A., \& van Houweling, E. (2015). Upgrading domesticplus systems in rural Senegal: An incremental income-cost (ic) analysis. Water Alternatives, 8(3), 317-336. https:// www.wateralternatives.org/index.php/all-abs/294-a8-3-2/file

Kyle, J., \& Resnick, D. (2016). Nepal's 2072 federal constitution: Implications for the governance of the agricultural sector: Vol. 1589. Intl Food Policy Res Inst.

Mikhail, M. (2010). Opportunities revealed by the Nepal multiple-use water services experience. Waterlines, 29(1), 21-36. https://doi.org/10.3362/1756-3488.2010.003

Mikhail, M., \& Yoder, R. (2008). Multiple use water service implementation in Nepal and India: Experience and lessons for scale-up. International Development Enterprises (iDE), the Challenge Program on Water and Food (CPWF), and International Water Management Institute (IWMI).

Moriarty, P., Butterworth, J., Martin, A., Morris, M., Nicol, A., \& Cousins, T. (2003). Productive use of domestic water supplies: How water supplies can play a wider role in livelihood improvement and poverty reduction. IRC Thematic Overview Paper. International Water Supply and Sanitation Centre (IRC), The Hague, The Netherlands.

Moriarty, P., Butterworth, J., \& van Koppen, B. (2004). Beyond domestic: Case studies on poverty and productive uses of water at the household level. Technical papers series 41. Vol. 7. International Water Supply and Sanitation Centre (IRC).

Polak, P., Adhikari, D., Nanes, B., Salter, D., \& Surywanshi, S. (2004). Transforming rural water access into profitable business opportunities. Beyond Domestic: Case studies on poverty and productive uses of water at the household level (Technical Paper Series; no. 41). IRC International Water and Sanitation Centre, Delft, the Netherlands.

Pradhan, P., Rajouria, A., Bhandari, P., Pandey, V. P., \& van Koppen, B. (2019). Institutionalization of multiple use water system (MUS) in Nepal. 
International Water Management Institute (IWMI).

Rautanen, S. L., van Koppen, B., \& Wagle, N. (2014). Community-driven multiple use water services: Lessons learned by the rural village water resources management project in Nepal. Water Alternatives, 7(1), 160$177 . \quad$ https://www.water-alternatives.org/index.php/alldoc/arti cles/vol7/v7issue1/239-a7-1-10/

Renwick, M. E. (2001). Valuing water in a multiple-use system-irrigated agriculture and reservoir fisheries. Irrigation and Drainage Systems, 15(2), 149-171. https://doi.org/10.1023/A:1012950912505

Smits, S., Atengdem, J., Darteh, B., van Koppen, B., Moriarty, P., Nyarko, K., Ofosu, E., Venot, J.-P., \& Williams, T. (2011). Multiple use water services in Ghana scoping study. International Water Management Institute (IWMI).

van Koppen, B., Moriarty, P., \& Boelee, E. (2006). Multiple-use water services to advance the millennium development goals (Research report, 98). International Water Management Institute (IWMI).

van Koppen, B., \& Smits, S. (2012). Multiple use water services: Scoping study synthesis (Research report). International Water Management Institute (IWMI).

van Koppen, B., Smits, S., Moriarty, P., de Vries, F. P., Mikhail, M., \& Boelee, E. (2009a). Multiple-use water services (MUS) (CPWF project report). International Water Management Institute (IWMI).

van Koppen, B., Smits, S., Moriarty, P., Penning de Vries, F., Mikhail, M., \& Boelee, E. (2009). Climbing the water ladder: Multiple-use water services for poverty reduction (TP series; no. 52). International Water and Sanitation Centre (IRC) and International Water Management Institute (IWMI).

Vogt, W. P., Gardner, D. C., Haeffele, L. M., \& Vogt, E. R. (2014). Selecting the right analyses for your data: Quantitative, qualitative, and mixed methods. Guilford Publications.

World Bank. (2018). International development association program document for a proposed development policy credit to Nepal for the first programmatic fiscal and public financial management development policy credit (Report No. 121391-NP). 